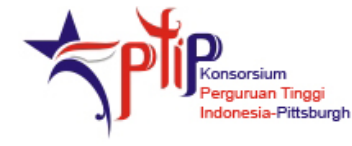

\title{
Action Research on the Implementation of Teaching for Active Learning in Two Elementary Madrasahs in Aceh
}

\author{
Sulastri Muhammad Syah,,${ }^{\mathrm{a},}$ Yulia Fitri, ${ }^{\mathrm{a}}$ Bainuddin Yani, ${ }^{\mathrm{a}}$ Adlim, ${ }^{\mathrm{a}}$ \\ Tri Qurnati, ${ }^{\mathrm{b}}$ Nursalmi, ${ }^{\mathrm{b}}$ Tasnim Idris, ${ }^{\mathrm{b}}$ and Sabarni ${ }^{\mathrm{b}}$

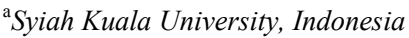 \\ ${ }^{\mathrm{b}}$ State Islamic Studies Institute Ar-Raniry, Indonesia
}

\begin{abstract}
Teaching for active learning is an instructional strategy that has been shown to improve student achievement. Many of its advocates also stress its contribution to the development of democratic dispositions in school children. It has, therefore, become a popular reform intended to improve teaching and learning in schools around the world, including Indonesia, where it was a key component of training conducted in Aceh under the auspices of the USAIDfunded Decentralized Basic Education 2 Project (DBE2). In order to gauge the extent to which teaching for active learning was being adopted in Aceh, a team of lecturers from Syiah Kuala University and the State Islamic Studies Institute in Banda Aceh conducted an action research project designed to identify the challenges faced by teachers attempting to teach for active learning in two elementary-level madrasahs as well as strategies that might assist them in that effort. The results of our research show that, while the initial training provided to teachers heightened their consciousness of teaching for active learning and inspired some to experiment with the new teaching methodology, teachers' understanding and acceptance of active learning was still tentative and could be undermined without effective leadership and long term mentoring.
\end{abstract}

\begin{abstract}
Abstrak
Pengajaran untuk pembelajaran aktif (active learning) merupakan strategi mengajar yang telah terbukti meningkatkan prestasi siswa. Banyak pendukungnya menekankan kontribusi strategi ini dalam pengembangan sikap demokratis siswa. Karena itu, strategi ini menjadi popular di programprogram perbaikan kualitas belajar mengajar di berbagai sekolah di dunia, termasuk Indonesia, dan menjadi komponen utama dalam pelatihan guru di Aceh dibawah program Decentralized Basic Education (DBE2) bantuan USAID. Guna mengukur sejauh mana active learning diadopsi di Aceh, tim dosen Universitas Syiah Kuala dan Institut Negeri Agama Islam (IAIN) di Banda Aceh mengadakan proyek penelitian tindakan untuk mengidentifikasi kendalakendala yang dihadapi guru yang berusaha mengajar menggunakan active learning di dua madrasah ibtidaiyah, dan memformulasi strategi yang mungkin dapat membantu para guru. Walaupun pelatihan awal mampu meningkatkan kesadaran dan persepsi guru terhadap pembelajaran active learning dan memotivasi mereka untuk bereksperimen dengan metode baru ini, hasil penelitian menunjukkan bahwa, para guru masih memperlihatkan tingkat penerimaan dan pemahaman yang tentatif dan bisa berkurang jika tidak diiringi dengan kepemimpinan yang efektif dan bimbingan jangka panjang.
\end{abstract}

Key Words: Active Learning, Teaching, Aceh, Madrasah

\section{Introduction}

The Indonesian province of Aceh and its capital Banda Aceh have attracted world-wide attention due to the protracted struggle (1976-2005) for the independence of Aceh (Reid 2006) and the

*Corresponding author. Address: Faculty of Education, Syiah Kuala University, Banda Aceh, Nanggröe, Aceh Darussalam, Indonesia. Email: sulastri.fkip@gmail.com. disastrous tsunami that struck the province on 26 December 2004. Both tragedies severely affected all sectors of Acehnese society, including education. Many teachers left the province during the rebellion, and as many as 600 schools were burned (Moore 2003). Then the tsunami completely destroyed or damaged 1,893 units of 21,893 total schools and killed approximately 2,640 teachers out of 22,615 total teachers in the province (National Planning Agency 2008). The sheer scale of the disaster elicited an international humanitarian and development assistance response of 
unprecedented scope: by 2009 the educational infrastructure had been rebuilt and new teachers recruited.

Many international organizations participated in the redevelopment of the physical and human infrastructure of education in Aceh after the tsunami disaster. The United States Agency for International Development, for example, through its Decentralized Basic Education 2 (DBE2) initiative, was extensively involved in helping to improve teaching and learning at all levels of Acehnese education. The DBE2 project trained hundreds of teachers in both public elementary schools (SD: sekolah dasar) and Islamic primary schools (MIN: madrasah ibtida'iyah negri) throughout the province. It also trained school principals and supervisors and members of school committees to support the changes teachers were attempting to implement in their classroom practices. One important element of that training was teaching for active learning.

\section{Why Active Learning?}

Recognition of the importance of students' active engagement in their own learning dates at least as far back as Jean-Jacques Rousseau (1762/1979) and has been a key element of most education philosophies-Pestalozzi, Froebel, Montessori, Dewey, Vygotsky, to name but a few-ever since (Dewey 1900, 1938; Vygotsky 1978; Rusk and Scotland 1979). Active learning is, at its most basic level, "any instructional method that engages students in the learning process (Prince 2004, 1). Active learning strategies emphasize the significance of the learner's involvement in the learning process and may involve independent inquiry, collaborative learning, self-awareness of the individual's own learning process, and purposeful adaptation of new knowledge to the learner's prior experience, current interests and future goals (Niemi 1997; Slavin 1997). Currently, there is an extensive body of empirical research that testifies to the importance of teaching for active learning in improving the academic performance of students at all levels (Prince 2004). In addition to its effectiveness in fostering academic achievement, active learning has also been credited with contributing to the development and maintenance of important democratic dispositions among learners. In eschewing traditional, top-down teacher student relations and encouraging critical thinking, choice, and active engagement, teaching for active learning is believed to contribute to the creation of a more democratic society (Rousseau 1762/1979; Dewey 1916; Freire 1970/1990).

For these reasons, teaching for active learning has become a common feature of educational reform efforts around the world from Europe (Stern and Huber 1997; Niemi 2002; Sturtevant and Linek 2007) to Central America (deBaissa, Chesterfield, and
Ramos 2002) to the Middle East (Ginsberg and Megahed 2008; Herrera 2008). Indonesia too has promoted teaching for active learning since at least the 1980 s through reform initiatives such as The Way of Active Learning (Cara Belajar Siswa Actif), Educational Unit Level Curriculum ${ }^{1}$ (KTSP: Kurikulum Tingkat Satuan Pendidikan), and Active, Creative, Effective and Joyful Learning (PAKEM: Pembelajaran Aktif, Kreatif, Efektif dan Menyenangkan). Despite the evidence of active learning's superiority as a pedagogical strategy over traditional transmission models of teaching however, widespread adoption of teaching for active learning strategies has proven difficult because it requires a significant break with how teachers themselves have been taught and a change in the culture of classrooms and schools that is not always supported by administrators or parents (Niemi 2002; Kimonen and Nevalainen 2005). Thus the DBE2 project's incorporation of teaching for active learning as one component of its training regime for teachers in Aceh complemented and enhanced previous efforts by the Ministry of National Education (MONE) to promote teaching for active learning nationwide.

The DBE2 training in teaching for active learning in Aceh was part of a nation-wide effort carried out in seven provinces across Indonesia. The training in Banda Aceh started 21 March 2007 and by November 2008, 41 trainings had been conducted in the city. The teaching for active learning effort started with National Field Staff Training and National Training of Trainers, which was replicated at the provincial level. The training focused on the active learning practice as well as mentoring strategies for teachers and principals. At the provincial level, Module Development Teams, consisting of local university lecturers who had been trained in active learning strategies, developed training modules in math, science, civic education and Bahasa Indonesia which incorporated active learning teaching strategies and the integration of technology in instruction. These training packages were rolled out to clusters of schools, each of which had been equipped with a learning resource facility where the training took place.

The training packages were delivered in a series of workshops over six days. These included a three-day school team workshop for teachers, school principals, school committee members, local MONE officials and local Ministry of Religious Affairs (MORA) officials. In this initial workshop participants were introduced to the practice of active learning, classroom management and assessment strategies for active learning as well as sample syllabi and lesson plans. The following workshop was a two-day Teacher Working Group which engaged teachers in discussion of lesson planning and specific subject matter. The final workshop was addressed to school principals, providing them with an understanding of active learning that would enable them to 
effectively mentor and supervise teachers who were attempting to introduce active learning strategies in their classrooms.

Training workshops were followed by 20 days of mentoring in participants' classrooms, which included peer and trainer observations. Each participant was observed in their classroom and mentored by members of the module development teams and master teacher trainers. Assignments completed by participants during the course of the workshops and mentoring period were collected into portfolios, which were reviewed by facilitators and then certified by a local university as equivalent to university credit, thus helping participants respond to the mandate of the 2005 Teachers and Lecturers Act requiring all teachers to hold or obtain a baccalaureate degree by 2015 . Teachers who completed the workshops and demonstrated satisfactory performance through the mentoring process were honored as Field Study Mentors.

\section{Purpose of the Study}

The literature on active learning, while presenting something of a consensus as to the usefulness of the strategy in promoting student achievement, is also candid about the difficulties of transitioning from traditional transmission models of teaching to teaching for active learning. Such a transition requires a break in professional habits that may have been acquired over many years of one's own schooling and teaching practice. It also disrupts students', administrators', parents' and colleagues' taken-forgranted assumptions about how school works. In short, transitioning to active learning strategies requires a cultural change in the classroom and the school (Niemi 2002; Kimonen and Nevalainen 2005). And in an Indonesian educational culture shaped by decades of centralization and top down administration, the cultural change required to disseminate active learning strategies is particularly difficult (Bjork 2003).

Cognizant, then, of the importance of teaching for active learning as well as the difficulties of implementing it widely in Indonesian schools, we wanted to know how teaching for active learning was faring in Acehnese schools after the DBE2 training. We wanted to understand how teaching for active learning is being implemented in Aceh and what challenges educators are facing as they attempt to teach for active learning in Aceh's elementary schools. We also wanted to understand successful implementations of teaching for active learning in Aceh's elementary schools so as to identify successful strategies that might assist teachers in other schools in adopting teaching for active learning. In order to investigate these questions a team of lecturers from Syiah Kuala University (UNSYIAH) and the State Islamic Studies Institute (IAIN Ar-Raniry) in Banda Aceh, some of whom had been involved in the DBE2 training of Acehnese teachers, designed and carried out a collaborative action research project (Stringer 2007) focused on the following questions:

- What do teachers do when they teach for active learning in the classroom?

- What are teacher perceptions of what supports are necessary for successful active learning?

- What are teacher perceptions of difficulties in implementing teaching for active learning?

- What are teacher perceptions of the effects of teaching for active learning with students?

- What are the principal's and school committee members' understandings and misunderstandings of teaching for active learning?

\section{Research Sites}

In the Indonesian system of national education, both the SD and MIN offer six years of schooling from the ages of six to twelve. Through most of Indonesia, the MIN requires additional subjects in Islamic learning beyond the standard curriculum. These include the holy book of Islam (Al-Quran), collections of the Prophet Muhammad's sayings as well as his practice of Islam (Hadith), the faith and moral of Islam (Aqidah ahlak), Islamic law (Fiqih), Islamic history, and the Arabic language. In Aceh, however, SD and MIN curricula are almost identical since the majority of community members are Muslim and the special autonomous political status of Aceh has allowed the local government to introduce Islamic teaching into local regulations, including those that govern education (Reid 2006).

The action research team from UNSYIAH and IAIN Ar-Raniry selected two MIN in the city of Banda Aceh-MIN Mesjid Raya and MIN Rukoh - to investigate whether the specifically religious mission of the madrasah had any impact on teaching for active learning and to complement the work of a second research team investigating the implementation of teaching for active learning in two SD in Banda Aceh. MIN Mesjid Raya is a modern school located on a main road roughly delineating the border between the rural and urban areas of the city. It is the oldest madrasah in Banda Aceh — established in 1959 - and enrolled 925 students in 2009. The school consists of sixteen classrooms, a library, a canteen and better than usual sanitation facilities. Given the level of enrollment, all grades have multiple sections, which requires a split schedule and six days per week attendance to accommodate all students. Class sizes average 42-45 students per classroom. This exceeds the national standard, which is 28 students per classroom. 
MIN Mesjid Raya has a staff of 28, twelve of whom are temporary teachers and three are administrative staff. None of the teachers have completed their bachelor's degrees; however, all have completed two years of university training in education - the minimum required under Indonesian law prior to the 2005 Teachers and Lecturers Act - and several are currently pursuing degrees at universities in Banda Aceh. Two hold national teaching certificates. Approximately 65 percent of the teachers are between 35- and 55-years-old, while roughly 10 percent are nearing retirement. All of the teachers participated in the DBE2 training. The parents of MIN Mesjid Raya come from a variety of socioeconomic classes in both urban and rural areas. They include laborers, small business persons, government employees, and professionals.

MIN Rukoh is located near the UNSYIAH and IAIN campuses in the city of Banda Aceh. The school's buildings were reconstructed after being destroyed in the tsunami on 26 December 2004. The school has thirteen permanent teachers and eight temporary teachers, eighteen of whom participated in the DBE2 training in 2007 and 2008. All teachers are women, with the exception of one man who coaches sports. The teachers are mostly young. MIN Rukoh enrolls 400 students in ten learning groups with an average of forty students per class. Students are tracked according to academic achievement, though they can move from one level to another based on their performance. The school also offers remedial instruction for those students who need it.

\section{Methods}

The research started in February of 2008 and concluded in April of 2010. Our inquiry was designed as an action research project (Stringer 2007). We selected this approach because we did not simply want to know what was happening with teaching for active learning in these schools, we wanted to assist them in their efforts to teach for active learning and to learn what we could that might help us disseminate teaching for active learning more widely in Aceh. As such, our investigation involved multiple cycles of data gathering, analysis, and refinement of focus leading to further data collection before finally settling on an intervention strategy. Data were collected through semi-structured interviews with teachers and principals, classroom observations, and focus group discussions with teachers as well as from documents such as lesson plans and classroom assessments. Overall, a total of fourteen interviews were conducted with teachers of mathematics, Bahasa Indonesia, civic education, social studies, Islamic law, Quran, hadith, sports, history and Islamic culture. A total of 22 classroom observations were carried out during the course of the project.
Interview and focus group data were recorded and transcribed. Observational data were collected in the form of field notes. All data were analyzed first holistically in order to identify themes emerging from the data and then categorically in order to identify patterns within different themes. In keeping with the perspective of Stephen Kemmis and Robin McTaggart (2000) on action research as involving multiple cycles of data collection and analysis, the team used data analysis after the initial rounds of data collection to re-direct subsequent rounds of data collection. Ultimately, the team reached a point at which we felt that we knew enough about the effort to teach for active learning in both schools that we were ready to intervene in the process.

\section{Findings}

\section{Teacher Awareness of Active Learning}

A significant portion of the teaching staff of both MIN Mesjid Raya and MIN Rukoh participated in the active learning workshops facilitated by DBE2. Others also received training on teaching for active learning from other organizations. One teacher explained, "Some of us got training from DBE2 or other nongovernmental organizations (NGOs), especially for math and science" (MIN Rukoh Teacher Interview). Teachers also reported participating in partnerships with the provincial level office of MORA which were intended to support teaching for active learning. DBE2 training was also followed up with mentoring by master teacher trainers, school supervisors and local MORA officials. The project also supported principals, teachers and school committee members to visit other schools which had been successfully using active learning strategies. Clearly, many of the teachers of both schools had had significant exposure to the practice of teaching for active learning.

\section{Implementation}

According to the teachers, both schools have made progress in implementing teaching for active learning: "Currently we are implementing active learning in teaching" (MIN Rukoh Teacher Interview). In a focus group discussion at MIN Mesjid Raya, however, teachers reported that implementation of active learning depended upon the subject taught. These teachers appeared to believe that active learning strategies were most feasible in subjects where there was strong student interest. When a member of the research team asked one Mesjid Raya teacher whether they were encountering difficulties in teaching for active learning, however, she replied "Insya'allah (God willing), so far it goes 
smoothly because the students are used to studying in groups and learning together" (MIN Mesjid Raya Teacher Interview). Other teachers reported that mathematics, science, Arabic, local content curriculum and life skills classes were being taught with active learning strategies.

Some teachers of individual subjects confirmed that they were indeed attempting to put into practice what they had learned in DBE2 trainings. In one focus group discussion, for instance, mathematics teachers described their practice of starting with individual work before putting students to work together in pairs and finally in groups as active learning. Science teachers in particular claimed to have embraced teaching for active learning. Working around their lack of laboratory space or equipment, these teachers talked of taking their students out of the classroom to observe plants or work in the school's herbal garden. They sometimes asked students to observe the weather and frequently assigned students to work in groups. And they attempted to construct thematic units to draw connections between science and Islamic values, thus contributing, in their understanding, to the cognitive, psychomotor and effective development of their pupils.

When one member of the research team asked a science teacher about students' note taking during experiments, however, she replied that note taking was not required during experiments because the concepts under study had been explained earlier in classes. This suggested to the team that this teacher, at least, may understand alternating between traditional, lecture-oriented class work and laboratory-type exercises as teaching for active learning. In fact, other teachers confessed that, while they were required to compose lesson plans that included active learning activities, they preferred to teach in their accustomed manner, which was lecturing.

Islamic studies teachers also described their efforts to teach for active learning. They reported using pictures as prompts to elicit group discussions about a topic related to the picture. These group discussions were then presented to the whole class and the results displayed on the classroom wall. Teachers would then evaluate their work, reinforce the lesson as necessary, and then assign homework. Teachers of Islamic law (fiqih) in particular reported using this strategy because students found pictures from newspapers or magazines attractive, and they could be used to spark conversations about various religious concepts.

Other teachers described their efforts to use active learning strategies in their classroom. One, for instance, used songs and games to energize her students in the morning. A Bahasa Indonesia teacher said "I applied the active learning model. I ask students to interview people around the school and then create a story and present it in class" (MIN Rukoh Teacher Interview). While science and math teachers reported teaching for active learning on numerous topics, some of the social studies, religion, and language teachers do not appear to be implementing it in their classrooms. One social studies teacher reported "I find it difficult to implement teaching for active learning because there is no special active learning training for social studies" (MIN Mesjid Raya Teacher Interview). Also, shortages of classroom space in the schools required teachers to move from one classroom to another and led school officials to permit community groups to use school facilities after hours. This interfered with teachers' efforts to display students' work, which they saw as an impediment to active learning.

\section{Old Habits and Misperceptions}

Based on our interviews and focus group discussions with teachers in MIN Mesjid Raya and MIN Rukoh it appeared that most teachers had received training in teaching for active learning and that those who had were attempting to implement their understanding of what they learned in their own classrooms. Our classroom observations, however, and ongoing interviews, shed more light on challenges some teachers faced as well as the extent to which teaching for active learning was being implemented. Our review of lesson plans for mathematics, Islamic morality, social studies, Bahasa Indonesia, and Islamic law, for instance, revealed that these teachers were not including active learning strategies in their instructional plans. One teacher explained, "We used to not necessarily teach as described in the lesson plan. We created the strategy as we taught without putting it in the lesson plan" (MIN Rukoh Teacher Interview). In our observations of some classrooms, especially those teaching the Quran and hadith, we found that the teachers encouraged memorization and used simple rewards and punishments to enforce compliance with learning objectives. Other teachers seemed to understand active learning as allowing pupils to play freely without specified roles or policies. "I apply active learning by letting students learn while playing without rules or policies” (MIN Mesjid Raya Teacher Interview).

Our interviews and focus groups in both schools, but particularly in MIN Mesjid Raya, offered important additional insights into teachers' and principals' perceptions of what teaching for active learning is. In addition to the misperception of active learning as simply unstructured play, teachers strongly associated teaching for active learning with group activities.

The learning process depends on the teacher, the subject matter, the topic and the material. For example, in Bahasa Indonesia conversation, students learn in pairs. In science, they 
are learning in groups. For me, I look at the material first, then see whether they have to work in groups or pairs. (MIN Rukoh Teacher Interview)

A mathematics teacher reported "I usually divide students into groups because this makes them focus on geometry materials like origami” (MIN Rukoh Teacher Interview). Other teachers expressed the view that if students are seated facing the front of the classroom, as in a theater, and students are not working in groups, then active learning is not taking place. This belief is at least partly shaped by teachers' perception that principals and supervisors assume that teaching for active learning requires students to be seated in small groups. One teacher recounted an observation of her class by the school principal. "I thought I had implemented active learning, but the supervisor said I had not. He said 'Your teaching was good but you have to set students in groups. Active learning must take place in groups"' (MIN Mesjid Raya Teacher Interview). These sorts of differences in understanding between teachers and their supervisors contribute to a sense of uncertainty about what exactly constitutes teaching for active learning and what does not, thus undermining teachers' confidence in themselves and their ability to teach for active learning.

\section{Doubts about Active Learning}

This tendency to equate active learning with group activity contributes to some teachers' doubts about the feasibility of active learning in their school because shortages of space make group activity problematic. One science teacher said that students became bored with attempts to conduct experiments inside the classroom. (Neither school has dedicated laboratories). But if she takes them outside, they are distracted by crowds of students engaged in sport activities in the same time and place. Other teachers report their reluctance to rearrange classrooms to accommodate group activities because they are concerned that this might annoy the teacher who uses the classroom immediately after them.

A number of teachers expressed concern about the noise and classroom management issues they associated with group activity and teaching for active learning. They insisted that, with 38-45 pupils in a single classroom, rearranging chairs for group activity was not feasible as students could not easily move around: "If we want to divide students in groups, they make noise when they keep moving the tables and chairs. Then when other teachers come to the classroom, they move the tables and chairs back into a traditional arrangement" (MIN Mesjid Raya Teacher Interview). Another teacher argued "Teaching for active learning is not suitable for the schools which have a large number of students because the classroom is narrow. When we divide the students in groups then, the classroom will be full and noisy" (MIN Mesjid Raya Teacher Interview).

Another frequently stated concern was teachers' need to meet annual curriculum benchmarks. These teachers believed that teaching for active learning was a less efficient use of instructional time, thus jeopardizing their prospects of meeting these deadlines. One teacher who worked with first year students said "I teach with active learning ... but it does not fit well with the semester and annual work plan. My students are not very capable, so I have to repeat the explanation many times, so I do not reach the curriculum target" (MIN Mesjid Raya Teacher Interview).

Another teacher claimed that before the implementation of active learning students were learning to read in Grade 1, but after implementing active learning, many were not reading even by Grade 2. Ibu Anggrek, a teacher at MIN Mesjid Raya, stated "We sometime teach with active learning approach but not all the time because we are worried that there will not be enough time to reach the curriculum target." Ibu Bugenvil complained "Teaching for active learning makes the teacher busier and complicates our lives at school. Every day we are asked to write lesson plans, which we did not do before. Active learning adds to our workload" (MIN Mesjid Raya Teacher Interview). Similar sentiments were expressed by religious studies teachers.

\section{The Role of School Leaders}

Our interviews with principals revealed that the principals of both schools had been trained in teaching for active learning. And both principals indicated that they tried to support their staff in teaching for active learning. "We enjoy active learning. We appreciate active learning and ask teachers to implement it" (MIN Rukoh Principal Interview). Another principal reported "As a principal, sometimes I do not have the capacity to guide teachers in active learning. In those situations I invite the expert to teach them" (MIN Mesjid Raya Principal Interview). The success of the principals in translating their avowed support for active learning into teaching for active learning in their schools' classrooms appeared to differ, however. MIN Rukoh teachers, for instance, said "Our principal always supports and guides us to implement active learning from preparing lesson plans, to teaching the class, to post class discussions" (Focus Group Discussion, MIN Rukoh). In addition, they were motivated and supported in their efforts to teach for active learning by the example of their principal: "We saw how the principal teaches. She creates opportunities for student experiences. For example, she took a rabbit to the class room to show what kind of food rabbits eat. Then she lets students 
go outside to pick several plants when she teaches about plants" (Focus Group Discussion, MIN Rukoh). A teacher from MIN Mesjid Raya, on the other hand, said, "Our principal always encourages us to implement active learning, but she rarely guides us in how to prepare good lesson plans or to discuss our difficulties in implementing active learning" (MIN Mesjid Raya Teacher Interview).

Our interview and focus group data contain frequent comments by teachers on differences of perception of active learning between teachers and supervisors. One mathematics teacher reported, "We are confused about how to implement active learning. What we mean by active learning is different from the supervisor" (Focus Group Discussion, MIN Mesjid Raya). Another teacher reported on an exchange with a supervisor after a classroom evaluation. "I thought I was implementing active learning, but the supervisor said I was not. The supervisor said 'your teaching was good but you have to set students in groups. Active learning must take place in groups" (MIN Mesjid Raya Teacher Interview). This principal in particular believes that active learning should be implemented in groups, that there should be displays of students' work, the student worksheets should be available, and that students should be more active than the teacher. This principal said, "Sitting in groups. I ask teachers to arrange the class by grouping, but not every day. The class can be rearranged, but not all teachers do that. Then, there should be a display of students' work and worksheets" (MIN Mesjid Raya Principal Interview). Such conflicting conceptions of what active learning is may be contributing to teachers' confusion about what they should be doing and to resistance to teaching for active learning. After such an incident, one teacher said "I did not want active learning and I do not implement it" (MIN Mesjid Raya Teacher Interview).

\section{Active Learning and Student Ability}

Some teachers claimed to teach for active learning but expressed the view that it is not effective because students have different levels of intelligence and comprehension. These teachers felt that teaching for active learning might be more effective for more advanced students but not for slower students. Teachers found it easier to implement teaching for active learning in core classes (with advanced students) rather than regular classes. One teacher said, "Actually the learning processes are the same, but students in core-class are more developed and active than regular classes where there is less competition and students are a little bit passive. In those classes the teacher is more active than students" (MIN Rukoh Teacher Interview). The teachers have to prepare better when they teach more advanced students because these students give very good responses and sometimes ask unpredictable questions. This was not something they observed from lower achieving students. They tended to be more passive and less responsive to assignments.

In interviews and focus groups, teachers reported relying primarily on exhortation, recognition, and small rewards to motivate students to be more active in their own learning. An Arabic teacher, for instance, said "I motivate students by saying if you are good in Arabic, you will travel abroad" (MIN Mesjid Raya Teacher Interview). Other teachers reported that they post students' assignments in the classroom to recognize good work. But other teachers, in response to researchers' questions about their strategies to motivate students, responded with comments that suggest limited efforts to motivate students to be more active in their classrooms. A math teacher said, "I ask students to work in groups or pairs" (MIN Mesjid Raya Teacher Interview). A teacher of Islamic law stated "I ask students to discuss the topic they learn and write the conclusion in student worksheets" (MIN Mesjid Raya Teacher Interview). A math teacher explained "Students learn individually first, and then they work in pairs, next they learn together in groups" (MIN Mesjid Raya Teacher Interview).

MIN Rukoh teachers said the impact of active learning in their school is that teachers started to think of alternative ways to teach, to motivate students, and to do assessments. They said their students were more confident to raise questions and express their opinions. They were more tolerant, respected other people's ideas and were able to work as a team. One teacher said, "Currently the students are braver than before. They are more active in giving opinions. Their achievement is also higher. Learning by playing makes students less bored" (MIN Rukoh Teacher Interview).

\section{Student Perceptions}

The students in MIN Rukoh seemed to respond positively to their teachers' efforts. They seemed to be proud of their achievements, especially if their work was posted in the classroom, an indication that they had earned their teacher's appreciation. When asked by a member of the research team about his favorite subject, one boy replied that mathematics was his favorite. "Don't you find it difficult?" the research asked. "We've already gotten used to it," the boy replied. "Ibu Manis (his teacher) played some games and then we do it again" (MIN Rukoh Student Interview). Another student expressed a preference for sports, while another liked science, even though there were no games. One boy reported that he preferred to work in groups of boys because girls talked too much and complained. Children described how their teacher walked around, observing their work in groups. If some classmates were inactive in group activities, the chairman of the group would report their inactivity to the teacher who would 
withhold a grade from that student. All in all, discussions with students in MIN Rukoh suggested that they were aware of their teachers' efforts to teach for active learning (though none of them used that term) and that they were responding positively.

\section{The Role of the School Committee}

Finally, school committee members in both schools expressed some familiarity with teaching for active learning which they had gained in DBE2 workshops, but did not see it as part of their role to be involved in promoting teaching for active learning in the classroom. "We participated in active learning training conducted by DBE2 and other NGOs four times," the head of the school committee said (MIN Rukoh School committee Member Interview). However, the school committee does not observe the active learning process directly in the classroom. "We rely on the principal to observe and report to us about implementation of teaching for active learning" (MIN Rukoh school Committee Member Interview). School committee members see their job as working with the principal in budget planning and expenditures for physical rehabilitation of the school, teacher welfare, honoraria for contract (non-permanent) teachers, extracurricular activities, et cetera. One teacher interviewed agreed: "The contribution of the school committee is to focus on developing infrastructure. They are not focused on supporting teachers to implement active learning" (MIN Rukoh Teacher Interview).

\section{Discussion}

The preponderance of the research team's data shows that there is a high level of awareness of teaching for active learning in both MIN Mesjid Raya and MIN Rukoh. The teachers, principals, local supervisors and school committee members are all familiar with the term and show evidence of varying degrees of familiarity with the concept itself. In addition, the data show a real intent to implement teaching for active learning in both schools. Both schools are trying and their efforts have shown some success. Teachers report that students are braver: they are more active in offering opinions and are more confident about raising questions and more comfortable in working in teams. At least one teacher said they are learning to be more tolerant, to respect other people's ideas. We cannot confirm from our data how widespread these student effects are, but these behaviors are certainly consistent with the sort of democratic dispositions some advocates of teaching for active learning claim the strategy promotes (deBaessa, Chesterfield, and Ramos 2002).

However, teachers' understanding of active learning is still developing. Our data suggest that they tend to associate active learning with physical indicators rather than cognitive or psychological processes. Among these subjects, teaching for active learning is heavily associated with group work, rearranging the physical space of classrooms, and displaying student work. These may all be positive departures from traditional teaching in both of these schools, but they are not necessarily teaching for active learning. Furthermore, the tendency among our subjects to focus on the outward physical display associated with active learning may be leading to problematic conceptions of teaching for active learning. For instance, some of our subjects seem to equate teaching for active learning with unstructured play. This is clearly not what active learning is about. Such a perception of active learning will no doubt undermine its credibility in the eyes of teachers, school leaders and parents.

While teachers and principals seem sincere in there expressions of support for the idea of teaching for active learning, they do have concerns. Their worry about the noise and lack of traditional classroom order suggests that their notion of a proper classroom is still quite traditional. They are concerned that teaching for active learning is a less efficient use of instructional time, thereby jeopardizing their ability to achieve curricular benchmarks mandated by the ministry. And some are clearly not convinced that their students are learning more through active learning. Others seem to resent a change in professional habits that they perceive as an additional burden rather than a better way to do what they do.

In some cases, these concerns are exacerbated by different understandings of teaching for active learning between teachers and principals. Several teachers told us that they thought they were teaching for active learning only to be told by their principal that they were not. This is no doubt confusing and frustrating and likely exacerbates a tendency among teachers socialized into a highly centralized professional culture to want to be told what to do (Bjork 2004). One social studies teacher, for instance, said that she could not teach for active learning because the training she attended was not specifically focused on teaching for active learning in social studies. Where the school leader was able to personally model a conception of teaching for active learning, as in MIN Rukoh, this confusion and frustration seemed to be neutralized and teachers felt more comfortable and committed to trying to teach for active learning. Where this was not the case, as in MIN Mesjid Raya, this confusion and frustration seemed to undermine teachers' willingness to try teaching for active learning and, at least in one instance, seemed to elicit explicit resistance.

\section{Intervention}


After months of fieldwork in both MIN Rukoh and MIN Mesjid Raya it became clear to the research team that MIN Rukoh was having more success in implementing teaching for active learning than MIN Mesjid Raya. Our data suggested the following difficulties in MIN Mesjid Raya:

- The principal, school committee members, supervisors and some teachers have misperceptions of teaching for active learning.

- A significant number of students do not support the implementation of active learning.

- The school committee activities do not focus on implementation of active learning.

- There seems to be a lack of communication between teachers and parents.

- There is a lack of effective mentoring of teachers to teach for active learning.

Based upon our analysis of the challenges MIN Mesjid Raya faced in implementing active learning strategies, we designed and implemented an intervention in the form of workshops for teachers, principals, school committee members and supervisors at MIN Mesjid Raya. The workshops focused on the use of low-cost instructional media, how to encourage student interest in learning by doing, how to incorporate different teaching methodologies and effective mentoring strategies.

The workshops were conducted at MIN Rukoh, with the MIN Rukoh principal and teachers acting as facilitators. The principal of MIN Mesjid Raya was invited, along with her teachers and school committee members. Members of the research team facilitated and observed the workshops. The principal of MIN Rukoh started the workshops with an explanation of the rationale of active learning and a discussion of various misconceptions of active learning. She also shared the strategy she uses to encourage active learning in her school and its impact on the school, the teachers and the students. She also described the role of the principal, teachers, school committee members, supervisors and students in the success of her school in implementing teaching for active learning. Almost all participants actively participated in the workshops, sharing their experience, knowledge and ideas with other participants.

The teachers of MIN Rukoh demonstrated teaching for active learning in their own classrooms while participants observed from the back of the room. They began by introducing the learning objectives to the students, arranging the students in several groups, distributing student worksheets and asking one of the students to describe and discuss a picture in each group. The teachers also demonstrated classroom management strategies, reinforcing and clarifying the involvement of each student in his or her group, helping students to perform their assigned tasks, monitoring student progress, and demonstrating her appreciation of students' work as it was presented to the class. They concluded with a summary of the lesson, asking students to reflect on their lesson before describing follow up activities and closing the class with an expression of her regards to the students' parents.

\section{Results of the Intervention}

The workshops did not dispel some parents' skepticism about teaching for active learning.

I saw a teacher who said she was teaching for active learning. The teacher gave an assignment to the students and then walked out of the classroom to have coffee and chat with other teachers. Is this active learning? I still doubt the active learning approach is effective teaching. Many students were taught without the active learning approach and they had very good academic achievement. What I see in this workshop might not be real. It must be set up to show that active learning is an effective approach. Although I saw in this school teachers implementing active learning, the classroom was set up very well, students were sitting in groups, there is lots of educational media in the classroom, students' portfolios are hung in the classroom, students are actively answering questions, and teachers acted as facilitators to encourage student activity. But this must be a play, not a real classroom. (MIN Mesjid Raya Parent Interview)

A month after the workshop one of the researchers interviewed this parent again to see if he had changed his estimation of teaching for active learning. "Active learning in MIN Rukoh is good. It's not just play," he said.

After seeing several teach for active learning in MIN Rukoh, and after I discussed this with other teachers, I believe this could also be done in MIN Mesjid Raya. However, it needs support from the school principal, who still doesn't understand active learning very well. I do not know why in our school (MIN Mesjid Raya), the school principal is often changed by the local MORA office before they finish their contract. Every new school principal will need some time to learn active learning and this makes less motivation for the teachers to implement it. Our current principal is now motivated to implement active learning after she observed MIN Rukoh and discussed it with the MIN Rukoh principal. However, right 
now she is being transferred to another school. (Interview, MIN Mesjid Raya Parent Interview)

In a follow up visit to MIN Mesjid Raya, we observed a meeting with the teachers in which the principal encouraged them to implement teaching for active learning in their school, especially for those who followed DBE2 trainings. The principal also performed a workshop on the school action plan proposal to seek budget support to offer an active learning workshop in their school where the MIN Rukoh teachers and the principal would be invited as resource persons. However, before this plan could be implemented, the principal had been transferred to another school by the local MORA office.

An Arabic language teacher we interviewed in this follow up visit expressed her belief that teaching for active learning was effective and that it could be implemented in her school just as it was in MIN Rukoh. However, when we observed classes in MIN Mesjid Raya after the intervention, we found that there was not much change in the teaching. The students were sitting in groups, and in the corner of the classroom there was a reading corner, a market corner, and a posting of rewards just as we saw in MIN Rukoh, but the teaching was still quite traditional: the teacher speaking and the students passive. The social science teacher we observed just read off her notes and asked students to write down what they heard. She explained some sentences or words that she thought might be new to the students. She never attempted to relate the lesson to the students' lives or their environment. The questions she asked of the students did not generate student thinking. The students only answered "yes" or "no" or chose the answer listed. There was a stark difference, however, in the science class we observed in the same school. The teacher was highly motivated to teach. Students actively participated in their own learning. The learning seemed contextualized. The teacher helped the students to think critically. The students looked happy.

\section{Conclusion}

In our final interview with the school supervisor, he reported that "recently the teachers in MIN Mesjid Raya have improved their teaching strategy in comparison with their previous performance. I supervised them all. Some felt upset with me because I gave them a lower grade. I expected that this will get a negative response at first, but I know they have been working better" (MORA School Supervisor Interview). Clearly, while workshops can be effective in raising the awareness of teachers about the advantages of teaching for active learning and may lead some teachers to experiment with new teaching strategies, our investigation confirms the findings of Hannele Niemi (2002) and
Elija Kimonen and Raimo Nevalainen (2005) that school-wide adoption of active learning requires a change in school culture, and cultural change is not easy or fast. Workshops alone are not enough. Much depends upon effective leadership, continuity of effort, and long-term mentoring and support of teachers.

\section{Note}

1. Educational Unit Level Curriculum (KTSP: Kurikulum Tingkat Satuan Pendidikan) is a basic curriculum framework derived from the national curriculum for $\mathrm{K}-12$ for the purpose of providing guidance in the formulation of educational unit level curriculum and syllabus to each educational unit.

\section{References}

Bjork, Christopher. 2004. "Decentralization of Education, Institutional Culture and Teacher Autonomy in Indonesia." International Review of Education 50 (3/4): 245-262.

Bjork, Christopher. 2003. "Local Responses to Decentralization Policy in Indonesia." Comparative Education Review 47 (2): 184-216.

de Baessa, Yetilú, Ray Chesterfield, and Tanya Ramos. 2002. "Active Learning and Democratic Behavior in Guatemalan Rural Primary Schools." Compare: A Journal of Comparative and International Education 32 (2): 205-218

Dewey, John. 1900. The School and Society \& the Child and the Curriculum. Chicago: University of Chicago Press.

Dewey, John. 1916. Democracy and Education. New York: Macmillan.

Freire, Paulo. 1970/1990. Pedagogy of the Oppressed. New York: Continuum.

Ginsburg, Mark B. and Nagwa M. Megahed. 2008. "Global Discourses and Educational Reform in Egypt: The Case of Active-Learning Pedagogies." Mediterranean Journal of Educational Studies 13 (2): 91-115.

Herrera, Linda. 2008. "Education and Empire: Democratic Reform in the Arab World? International Journal of Educational Reform 17 (4): 355-373.

Kemmis, Stephen, and Robin McTaggart. 2000. "Participatory Action Research." In Handbook of Qualitative Research, ed. Norman K. Denzin and Yvonna S. Lincoln (pp. 559-604). Thousand Oaks, CA: SAGE Publications.

Kimonen, Eija, and Raimo Nevalainen. 2005. "Active Learning in the Process of Educational Change." Teaching and Teacher Education 21 (6): 623-635. 
Moore, Matthew. 2003. "Aceh Education Becomes Forgotten Casualty of War." The Sunday Morning Herald. November 24. Available online at: http://www.smh.com.au.

National Planning Agency (Blog Bappenas). 2008. Master Plan of Post-Disaster Recovery for NAD Province and Nias Islands [Rencana Induk Pemulihan Pascabencana Di Provinsi NAD Dan Kepulauan Nias]. Jakarta: National Planning Agency. Available online at: http://www.bappenas.go.id.

Niemi, Hannele. 2002. "Active Learning-A Cultural Change Needed in Teacher Education and Schools." Teaching and Teacher Education 18 (7): 763-780.

Niemi, Hannele. 1997. "Active Learning by Teachers. In Active Learning for Students and Teachers: Reports from Eight Countries, ed. David Stern and Günter L. Huber. New York: Peter Lang.

Prince, Michael. 2004. "Does Active Learning Work? A Review of the Research." Journal of Engineering Education 93 (3): 223-231.

Reid, Anthony. 2006. Verandah of Violence: The Background of the Aceh Problem. Seattle, WA: University of Washington Press.

Rousseau, Jean-Jacques. 1762/1979. Emile. New York: Basic Books.

Rusk, Robert, and James Scotland. 1979. Doctrines of the Great Educators. New York: St. Martin's Press.

Slavin, Robert. E. 1997. "Cooperative Learning Among Students." In Active Learning for Students and Teachers: Reports from Eight Countries, ed. David Stern and Günter L. Huber. New York: Peter Lang.

Stern, David, and Günter Huber, eds. 1997. Active Learning for Students and Teachers: Reports from Eight Countries. New York: Peter Lang.

Stringer, Ernest. 2007. Action Research. 3rd ed. Thousand Oaks, CA: SAGE Publications.

Sturtevant, Elizabeth, and Wayne Linek. 2007. "Secondary Literacy Coaching: A Macedonian Perspective." Journal of Adolescent and Adult Literacy 51 (3): 240-250.

Vygotsky, Lev S. 1978. Mind in Society: The Development of Higher Psychological Processes. Cambridge, MA: Harvard University Press. 